\title{
Commentary: We need to know more about erythropoietin
}

\author{
Michael N. D'Ambra, MD
}

Murillo-Berlioz and colleagues ${ }^{1}$ present a case report of thrombosis after coronary artery bypass graft surgery in a patient who was a practicing Jehovah's Witness (JW). Their patient, who was without known preoperative thrombosis risk, was treated preoperatively with parenteral iron, folate, vitamin B12, and 8 daily subcutaneous doses of epoetin (EPO) Alfa-epbx 300 units/kg. The patient suffered submassive venous plus arterial thromboses on postoperative day 10 , having doubled her platelet count to 424,000 on admission for thrombectomy. Hypercoagulable workup was negative. EPO is known to increase platelet as well as red cell production.

EPO is a hypoxia-induced hormone produced in the kidney that stimulates hematopoiesis in the bone marrow. As a therapeutic agent, recombinant EPO is used in treating various types of anemia, including anemia of end-stage renal disease and cancer-related anemia on chemotherapy. EPO use in heart surgery was never approved by the Food and Drug Administration based on a negative randomized controlled trial of low-dose EPO in $1997 .^{2}$ There has not been another cardiac surgical randomized controlled trial since that time. However, there have been numerous reports and case series using high-dose EPO in patients who are JW and others in whom red cell transfusion is not an option-as part of a multidisciplinary blood-conservation regimen focused on enhancing red cell mass and on reducing blood loss.

In a 144-patient retrospective case comparison study of cardiac surgical patients who were JW, Tanaka and colleagues ${ }^{3}$ did not report increased thrombosis with the use

From Harvard Medical School (retired), Boston, Mass; and Division of Cardiac Surgery, University of Maryland School of Medicine, Baltimore, Md.

Disclosures: The author reported no conflicts of interest.

The Journal policy requires editors and reviewers to disclose conflicts of interest and to decline handling or reviewing manuscripts for which they may have a conflict of interest. The editors and reviewers of this article have no conflicts of interest.

Received for publication July 24, 2020; revisions received July 24, 2020; accepted for publication July 24, 2020; available ahead of print July 31, 2020.

Address for reprints: Michael N. D'Ambra, MD, Division of Cardiac Surgery, University of Maryland Baltimore Medical Center, 110 S Paca St, 7th Floor, Baltimore, MD 21201 (E-mail: mdambra@gmail.com).

JTCVS Techniques 2020;4:158-9

2666-2507

Copyright (C) 2020 The Authors. Published by Elsevier Inc. on behalf of The American Association for Thoracic Surgery. This is an open access article under the CC BY-NCND license (http://creativecommons.org/licenses/by-nc-nd/4.0/).

https://doi.org/10.1016/j.xjtc.2020.07.024

of EPO. They presented evidence that enhancing red cell mass with preoperative erythropoietin and iron therapy to a target hemoglobin level of $12 \mathrm{~g} / \mathrm{dL}$ is associated with a reduction in major adverse events in patients refusing blood transfusion.

In an editorial for the study of Tanaka and colleagues in the Journal we asked "why aren't we doing this for everyone?" - -meaning a multidisciplinary bloodconservation regimen. We also called for further comprehensive study of patients who are JW undergoing heart surgery with such blood-conservation methods as used in this present report by Murillo-Berlioz and colleagues. Murillo-Berlioz and colleagues will no doubt be cited in the future revisions of guidelines for blood conservation in cardiac surgery. ${ }^{5,6}$

The Society of Thoracic Surgeons database and other national registries would be ideal places to gather risk-benefit data to inform future guideline development on the use of EPO in cardiac surgery. Murillo-Berlioz and colleagues report an important critical event but cannot answer the questions raised. For that, the need for robust data is clear. The accuracy of future guideline development would be enhanced by it.

\section{References}

1. Murillo-Berlioz A, Guinn NR, Levy JH, Milano CA. Arterial and venous thrombosis complicating coronary artery bypass grafting after use of epoetin alfa-epbx. J Thorac Cardiovasc Surg Tech. 2020;4:154-5.

2. D'Ambra MN, Hillman R, Jones J, Kim HC, Rawitscher R, Schnaper H, et al. The effect of recombinant human erythropoietin on transfusion risk in coronary bypass patients. Ann Thorac Surg. 1997;64:1686-93. 
3. Tanaka A, Ota T, Uriel N, Asfaw Z, Onsager D, Lonchyna VA, et al. Cardiovascular surgery in Jehovah's witness patients: the role of preoperative optimization. $J$ Thorac Cardiovasc Surg. 2015;150:976-83.

4. D'Ambra MN, FitzGerald D, Kaufman RM, Shekar P. Blood conservation: why aren't we doing this for everyone? J Thorac Cardiovasc Surg. 2015;150:984-5.

5. Society of Thoracic Surgeons Blood Conservation Guideline Task Force, Ferraris VA, Brown JR, Despotis GJ, Hammon JW, Reece TB, et al. 2011 update to the Society of Thoracic Surgeons and the Society of Cardiovascular
Anesthesiologists blood conservation clinical practice guidelines. Ann Thorac Surg. 2011;91:944-82.

6. Task Force on Patient Blood Management for Adult Cardiac Surgery of the European Association for Cardio-Thoracic Surgery (EACTS) and the European Association of Cardiothoracic Anaesthesiology (EACTA), Boer C, Chairperson E, Meesters MI, Milojevic M, Benedetto U, et al. 2017 EACTS/EACTA guidelines on patient blood management for adult cardiac surgery. J Cardiothorac Vasc Anesth. 2018;32:88-120. 